\title{
Impact of Accounting Information on Share Price: Empirical Evidence from Pakistan Stock Exchange
}

\author{
Muhammad Asif \\ Department of Economics and Finance \\ MS. Muhammad Ali Jinnah University Karachi, Pakistan \\ E-mail: muhammad.aseeph@gmail.com
}

Kashif Arif

Faculty of Business and Accountancy, University of Malaya, Malaysia

Waqar Akbar

Faculty of Business and Accountancy, University of Malaya, Malaysia

Received: April 15, 2016

doi: 10.5296/ifb.v3i1.9323
Accepted: May 6, 2016 Published: June 6, 2016

URL: http://dx.doi.org/10.5296/ifb.v3i1.9323

\begin{abstract}
Purpose-The purpose of this paper is to examine the relationship between accounting information and share price. In order to achieve this, a model that includes specific accounting ratios (earning per share, book value per share, capital employed per share and operating cash flow per share) and shares a price is developed.

Design/methodology/approach - The data were collected from the companies listed in KSE-30 index. The time frame spans from 2006 to 2013 and OLS regression models were used to examine the relationships

Findings - The resulting evidence suggest that accounting information parameters have significant influence on share price and they have joint explanatory power in determining stock prices. This research finds the consistent results with pervious empirical researches.

Originality/value - The present study adds to the existing literature by examining the impact of accounting information on share prices within the context of an emerging capital market such as Pakistan Stock Exchange using KSE-30 companies. This is believed to be the first study
\end{abstract}


which considers the aforementioned issues in the Pakistan's capital market environment.

Keywords: Accounting Information, EPS, BV, CE, OCF, Share price 


\section{Introduction}

The ultimate goal of almost all firms is to increase their bottom line. Firms probably have distinct policies regarding wealth distribution however if they fail to increase their profits they are likely to face the issues to support their activities through raising capital. As a result increasing the shareholders' value is important for both the shareholders' and the management of the firm.

The value of any publicly listed firm can be derived from its share price. Nevertheless, share prices are volatile due to the impact of macro and micro economic factors. The managers usually depend on accounting information for measuring the performance of firm and this information is also of interest for the potential investor to select appropriate stock.

Numerous studies in this field focusing earnings however in recent years' equity book value are included as an additional variable and the residual income model is adopted as the theoretical base of the studies. Moreover, residual income measures are now in fashion of the business community as determinant of financial performance. Given such trends, it is relevant to ask how well they perform. The changes in stock price correlate and associate with change in financial information. This theory was developed by Ball and Brown in 1968. They established that if a listed company booked surplus profit then investors could earn unusual return. That phenomenon confirmed the association with the company's profit and share price. The company's share price is an inclusive indication of the company's future expected earnings. Further study done by Ball in 1995 observes equity market strength over fluctuation due to speculation. So the knowledge in accounting information is not sufficient in an equity market. Other factors can also have impact on it. Ohlson (1995) did numerous dynamic efforts for setting up the evaluation model. His model is based on future earning, dividend and book-value. According to an efficient market hypothesis (EMH), PSX (Pakistan Stock Exchange) is shown a weak inefficient market, because less information is available for an investors, and highly speculative market. Majority of investors invest on the basis of a financial annual or quarter-based report. They use different accounting parameters like price to an earnings ratio, book to price ratio, earning per share or historical share price pattern. The changes in accounting information ought to prompt change in the share price, if accounting data is helpful to illustrate the price. The question is whether there is a major investment relationship between the $\mathrm{B} / \mathrm{P}$ ratio, $\mathrm{P} / \mathrm{E}$ ratio and other ratios etc. with the shares valuation. So it's necessary to systematically investigate the relationship between share prices and accounting factors in the long run. This empirical paper examines the relationship between accounting factors and share prices.

\section{Literature Review}

Several empirical studies have been done to showing the influence of accounting information on stock prices. The accounting information is an effective tool to anticipate the share prices. The foundation of this research was given by Ball \& Brown (1968) establishing the argument that if a company has surplus profit then the investors can earn unusual return. The phenomenon confirmed the association of organizational profit and share prices. Ohlson (1995) did numerous dynamic efforts for setting up the evaluation model. His model is based 
on future earning, dividend and book-value.

Agostino, Drago, \& Silipo (2011) Concluded that the value relevance of earnings, book value, dividend and operating cash flow significantly influence on the share prices. Yu \& Huang (2005) examine that the financial data could influence shares value. It demonstrated the key financial information the significant correlation with shares' price and more suitable and precise decision-making tools for investors. The studies have focused on the relationship between financial and shares esteem; then, they have explored the association between financial information and shares esteem, and how the financial information has an impact on shares value.

Wang, Fu, \& Luo (2013) examined the relation between financial information and stock price. The company's results of operations were based on the Shanghai Stock Exchange listed 60 companies in 2011. The found a significant positive relationship between the degrees of change is the performance by the capital gains. Hejazi, Jafari, \& Heidarpoor (2011) considered the stock exchange response of listed companies financial profit data in Tehran stock exchange. This exploration inspected the relationship between shares return and equity markets in the manufacturing concern companies in the Tehran Stock Exchange from 2000 to 2004. Iranian equity investors mostly consider operating profit in combination to the operating cash flow and net profit.

Christie \& Chalevas (2010): investigated that accounting ratio and information correlate with stock return, focused on Greece, period cover 2004-2006. This research finds that the significant growth in operating activities (net profit) of a company positively affects stock returns. The sample of 2,164 companies in this research has concentrated on assessment of shares value. Menaje (2012) gets negative relationship ROA with share price and strong positive impact on share prices in the Philippines Stock Market

Glezakos, Mylonakis, \& Kafouros (2012) studied the influence of certain accounting information on the path of shares price. They examined the relationship of profit per share and book-value and shares value. The sample size was 38 listed companies in the Athens Stock Market amid the 1996-2008 periods. They concluded that the EPS and book-value significantly influence on the share price. The investors of Athens are more focused on financial data of companies.

Pathirawasam \& Chandrapala (2013) investigate the relationship between book-value and share-value. The research was done on the Colombo Stock Exchange (CSE) in the Sri Lanka from 2005 to 2009. They applied pooled cross-sectional regression. The explorations uncover that book-value is more value significant than the income in the Sri Lanka. M. G. P. D., M., \& Prabath, U.S. (2014) used Dividend per share, Earning Per share and Book value they get positive influence on Colombo Stock Exchange (CSE) share prices. Adaramola \& Atanda (2014) examined the relationship between accounting information and the Nigerian stock market behavior. In this research sample size of the firms were 57 and covered 20 years from 1991 to 2010. The accounting information based on earnings, dividend, book value and cash flows used as an independent variable to predict share prices of the firms. The result of this research indicates that the accounting information has the capability to significantly influence 
share prices of firms.

Agostino, Drago, \& Silipo (2010) in this research scholars examined impact of accounting standards IFRS on European banking share prices. The researcher explored the relationship between the market valuation of accounting information in the European banking industry. Ghayoumi et al. (2011) examined the impact of earning per share and book value per share on share prices in Tehran stock exchanges.

\section{Methodology}

The sample of firms selected for the study is taken from KSE 30-Index of PSX (Pakistan Stock Exchange), and covers the eight-year period from 2006 to 2013. All firms with available data for each of the variables are included in the full sample regardless of industry sector, financial year-end or any other distinguishing characteristic. In this way, the regressions are run with the largest possible samples and the minimum selection bias.

\subsection{Definition of Variables}

The variables used in the basic empirical model is the earning per share (EPS), Book value per share (BVPS), Capital employed per share (CEPS) and Net Operational cash flows per share (NOCEPS) as the independent variables while Stock returns as share price.

Earnings Per Share

Book value per share

Capital employed per share

Net operational cash flow per share
(EPS)

(BVPS)

\section{(CEPS)}

(NOCFPS)

\subsubsection{Earning Per Share}

Zhu (2003) found a significant positive correlation between share values and earn per share. Michalis Glezakos (2012) found the positive correlation between EPS and share price. Here in this research EPS positive and incremental change or vice versa.

EPS $=$ Net profit / Outstanding Number of share

$$
S P=\alpha+\beta 1 E P S+\epsilon
$$

\subsubsection{Book Value Per Share}

Another very strong accounting information tool is Book value per share. One of the objectives of this study is to observe exactly the association between firms' share value in capital market and book value, utilizing Pakistan's recorded (KSE-30 Index) Combination of Book value and market value have three situations to guide the risk factor. Literature show that mostly researches found positive association of stock price and book value consider as a real and true value of share according a balance sheet.

Book Value $=$ Total Equity / outstanding number of share 


$$
S P=\alpha+\beta 1 B V P S+e
$$

\subsubsection{Capital Employed Per Share}

The use of capital structure is considered as one of the mechanisms to mitigate the agency costs and thereby increase firm performance (Berger \& Bonaccorsi, 2006). Accordingly, a positive relationship is expected between debt capital and firm performance. On the contrary, pecking order theory suggests a negative relationship between debt capital and firm performance (Donaldson, 1961; Myers, 1984; Myers \& Majluf, 1984).

Capital Employed per share $=$ Long term liability +Equity $/$ No. Outstanding share

$$
S P=\alpha+\beta 1 C E P S+e
$$

\subsubsection{Net operational Cash Flow Per Share}

It's a realistic figure for how much cash is generated from operational activities. This paper investigates the impact of Net operational cash flows on stock value rather than accrual basis.

NOCF=Accrual base net profit + Non cash expenses +/- Current assets \& Current Liabilities

$$
S P=\alpha+\beta 1 \text { NOCFPS }+e
$$

Final Model

$$
S P=\alpha+\beta 1 E P S+\beta 2 B V P S+\beta 3 C E P S+\beta 4 N O C F P S+e
$$

Where

$\mathrm{SP}$ is average share price (SP)

$\alpha$ is constant

$\beta 1$ is coefficient of earnings per share (EPS)

$\beta 2$ is coefficient of book value per share (BVPS)

$\beta 3$ is coefficient of capital employed per share (CEPS)

$\beta 4$ is coefficient in net operating cash flow per share (NOCFPS)

e is error term

\section{Research Hypothesis}

Keeping in view the previous research the present study suggests the following main and sub hypotheses.

H1: Accounting information has a significant impact on share price of listed companies of KSE 30 index. 
H1a: Earning per share has a significant impact on share price of listed companies of KSE 30 index.

H1b: Book value per share has a significant impact on share price of listed companies of KSE 30 index.

H1c: Capital employed per share has a significant impact on share price of listed companies of KSE 30 index.

H1d: Net operating cash flow per share has a significant impact on share price of listed companies of KSE 30 index.

\section{Results and Discussion}

Table 1. Regression result (with capital employed)

\begin{tabular}{|l|l|}
\hline Constant & 32.74 \\
\hline & $(8.40)$ \\
\hline EPS & 3.51 \\
\hline & $(0.35)$ \\
\hline BVPS & 0.42 \\
\hline & $(0.11)$ \\
\hline CEPS & -0.03 \\
\hline & $(0.04)$ \\
\hline NOCFPS & 0.32 \\
\hline & $(0.15)$ \\
\hline R-squared & 0.59 \\
\hline No. of observations & 216 \\
\hline
\end{tabular}

$$
S P=32.74+3.51 . E P S+0.42 . B V P S-0.03 . C E P S+0.32 . N O C F P S+e
$$

The study had shown the meaningful role of EPS, BVPS and NOCFPS in determining the strength of Share price. The results are satisfactory in terms of standard analytic tests. The value of R-square is showing that $59 \%$ of the total variation in dependent variable is explained by independent variables excluding CEPS show no significant role to determination of share price. There is no problem of autocorrelation in the model as shown by the value of D.W stats. The overall performance of the model is satisfactory as shown by F-statistics refer to appendix for Eviews output. From the above factual information it is clearly obvious that there is a relationship between the change in share price as well as changes in accounting variables (EPS, BVPS, CEPS and NOPCFPS).

$$
S P=32.74+3.51 . E P S+0.42 . B V P S-0.03 . C E P S+0.32 . N O C F P S+e
$$

These independent variables results have significant impact on share prices expect CEPS. 
The CEPS is a negative relationship with share prices in this model. EPS is highly influence on share price. Its results show that investor too much focus on companies' annual earnings.

Table 2. Regression result (without capital employed)

\begin{tabular}{|l|l|}
\hline Constant & 32.74 \\
\hline & $(7.70)$ \\
\hline EPS & 3.55 \\
\hline & $(0.35)$ \\
\hline BVPS & 0.38 \\
\hline & $(0.10)$ \\
\hline NOCFPS & 0.28 \\
\hline & $(0.13)$ \\
\hline R-squared & 0.59 \\
\hline No. of observations & 216 \\
\hline
\end{tabular}

$$
S P=32.47+3.55 . E P S+0.38 . B V P+0.28 . N O C F P S+e
$$

The model is run again without capital employed and all the dependent variables are significant the R-squared of the model is not changed and showing that capital employed has no significant impact over the share prices.

Table 3. Variance Inflation factor (VIF)

\begin{tabular}{|l|l|}
\hline Independent Variable & VIF \\
\hline EPS & 1.718 \\
\hline BVPS & 1.899 \\
\hline CEPS & 1.433 \\
\hline OCFPS & 1.277 \\
\hline
\end{tabular}

The Variance Inflation Factor (VIF) is used for measuring the degree of multi-collinearity of the ith independent variable with the other independent variables in a regression model. The VIF result show that significant results and there is no multi-collinearity found among the independent variables.

\section{Discussion}

Based on the above result, it is reasonably influential that accounting information plays a vital role in share valuation in PSX. Investors' center of attention is published accounting (Quarterly \& Annual) reports and further followed by historical patterns (technical analysis). 
The impact of the 2008 financial crisis remained up to 2012. There is strong evidence that share prices are influenced by company's earning and EPS in the context of PSX rather than other variables. The results of our study are coherent with the corresponding results of many relevant empirical studies, which were carried out in several stock markets of developed and developing countries. In Pakistan investors have different investment choices they may invest in property, fixed deposits, gold, and forexch etc. Due to Lack of knowledge and information (Arif, 2015) which implies that earning are much more relevant to the retail investors.

This research concludes those accounting variables such as earning per share. Book value and net operating cash flow have significant influences on share price for the period of 2006 to 2013, and endorse pervious researches. The results of the study are consistent with the previous empirical research and imply that the accounting variables are significant for forecasting the prices of stock traded in PSX.

Stock exchanges are barometers of the economies. According to this research PSX should take steps to attract small investors and to reduce risk factors and introduce derivative products. The market can run freely on its mechanism rather than manipulating by government institutions or market players. According to Efficient Market Hypotheses (EMH) Pakistan stock exchange is performing as a weak inefficient market where market operates on past or historical patterns. Due to lack of information and financial education (Arif, 2015) investors invest on past pattern basis. The recommendations of the study are as under:

1) Pakistan stock exchange required to introduce customized derivative product for different group of investors

2) Take hard and concrete steps against dirty speculation

3) Efficient risk management

4) Make sure Karachi stock exchange set direction without outside influence

5) Stock exchange system elements any type of cartel

6) Conduct different courses for portfolio management for small investors

7) Introduce sector wise Index

\section{Future Research}

Like most other empirical studies, this study has limitations, which also offer prospects for future research. Our findings are applicable and relevant to the KSE-30 Index firms. Therefore, employing in-depth studies, how can other accounting information variables influence on the stock prices. Continuous research in this area may explore more stock market anomalies. Efficient Risk Management's role in Pakistan stock exchange is another area of future research which is helpful to eliminate dirty speculation factors. Analyses of investment culture of Pakistani capital market where investors invest in real estate property, Gold and Bank rather than stock exchange. Customized indices help an investor to take better decision. Return base comparative analysis of PSX with real estate property, commodity market and money market returns is also a suggested area of research. 


\section{References}

Agostino, M., Drago, D., \& Silipo, D. B. (2011). The value relevance of IFRS in the European banking industry. Review of Quantitative Finance and Accounting, 36(3), 437-457. http://dx.doi.org/10.1007/s11156-010-0184-1

Anthony, A., \& Adewale, O. (2014). The Relationship between Financial Accounting Information and Market Values of Quoted Firms in Nigeria. Auditing and Business Ethics (GJCRA) An Online International Research Journal, 2014(1).

Arif, K. (2015). Financial Literacy and other Factors Influencing Individuals' Investment Decision: Evidence from a Developing Economy (Pakistan). Journal of Poverty, Investment and Development, iiste, 12.

Chandrapala, P. (2013). The Value Relevance of Earnings and Book Value: The Importance of Ownership Concentration and Firm Size. Journal of Competitiveness, 5(2), 98-107. http://dx.doi.org/10.7441/joc.2013.02.07

Charitou, A., Clubb, C., \& Andreou, A. (2003). The Effect of Earnings Permanence, Growth, and Firm Size on the Usefulness of Cash Flows and Earnings in Explaining Security Returns: Empirical Evidence for the UK. Journal of Business Finance \& Accounting, 8(5-6), 563-594.

Chen, P., \& Zhang, G. (2007). How do accounting variables explain stock price movements? Theory and evidence. Journal of Accounting and Economics, 43(2-3), 219-244. http://dx.doi.org/10.1016/j.jacceco.2007.01.001

Florou, C., \& Chalevas, C. (2010). Key accounting value drivers that affect stock returns: evidence from Greece. Emerald, 36(11), 903-916.

Gallizo, J. L., \& Salvador, M. (2006). Share prices and accounting variables: a hierarchical Bayesian analysis. Review of Accounting and Finance, 5(3), 268-278. http://dx.doi.org/10.1108/14757700610686813

Glezakos, M., Mylonakis, J., \& Kafouros, C. (2012). The Impact of Accounting Information on Stock Prices: Evidence from the Athens Stock Exchange. International Journal of Economics and Finance, 4(2). http://dx.doi.org/10.5539/ijef.v4n2p56

Hand, J. R. (2005). The Value Relevance of Financial Statements in the Venture Capital Market. The Accounting Review, 80(2). http://dx.doi.org/10.2308/accr.2005.80.2.613

Hejazi, R., Jafari, M., \& Karimi, A. (2011). The Information content of Accounting Variables In Companies listed in Tehran Stock Exchange (TSE). Business Management Dynamics, 1(2), 32-38.

Huang, X. (2004). China stock price reactions to financial announcements: evidence from segmented markets. Managerial Finance, 30(3), 62-73. http://dx.doi.org/10.1108/03074350410768976

Kothari, S. (2001). Capital markets research in accounting. Journal of Accounting and Economics, 105-231. http://dx.doi.org/10.1016/S0165-4101(01)00030-1 
Li, Q., Yang, J., Hsiao, C., \& Chang, Y. J. (2005). The relationship between stock returns and volatility in international stock markets. Journal of Empirical Finance. http://dx.doi.org/10.1016/j.jempfin.2005.03.001

Perera, R., \& Thrikawala, S. (2010). An empirical study of the relevance of accounting information on investor's decisions. ICBI .

Salvery, S. (1998). The Accounting Variable and Stock Price Determination. Studies in Economics and Finance, 18(2), 26-61.

Wang, J., Fu, G., \& Luo, C. (2013). Accounting Information and Stock Price Reaction of Listed Companies-Empirical Evidence from 60 Listed Companies in Shanghai Stock Exchange. Journal of Business and Management, 2(2), 11-21. http://dx.doi.org/10.12735/jbm.v2i2p11

\section{Appendix}

\begin{tabular}{|c|c|c|c|c|}
\hline \multicolumn{5}{|c|}{ Dependent Variable: SP } \\
\hline \multicolumn{5}{|c|}{ Method: Panel Least Squares } \\
\hline \multicolumn{5}{|c|}{ Date: 01/12/15. Time: 22:25 } \\
\hline \multicolumn{5}{|c|}{ Sample: 20062013} \\
\hline \multicolumn{5}{|l|}{ Periods included: 8} \\
\hline \multicolumn{5}{|c|}{ Cross-sections included: 27} \\
\hline \multicolumn{5}{|c|}{ Total panel (balanced) observations: 216} \\
\hline Variable & Coefficient & Std. Error & t-Statistic & Prob. \\
\hline EPS & 3.509289 & 0.353279 & 9.933478 & 0.0000 \\
\hline BVPS & 0.414931 & 0.107647 & 3.854532 & 0.0002 \\
\hline CEPS & -0.029779 & 0.043830 & -0.679414 & 0.4976 \\
\hline NOCFPS & 0.316858 & 0.144827 & 2.187843 & 0.0298 \\
\hline $\mathrm{C}$ & 32.73928 & 8.399377 & 3.897822 & 0.0001 \\
\hline R-squared & 0.587243 & \multicolumn{2}{|c|}{ Mean dependent var } & 115.2794 \\
\hline Adjusted R-squared & 0.579418 & \multicolumn{2}{|c|}{ S.D. dependent var } & 112.7820 \\
\hline S.E. of regression & 73.14176 & \multicolumn{2}{|c|}{ Akaike info criterion } & 11.44555 \\
\hline Sum squared resid & 1128790. & \multicolumn{2}{|c|}{ Schwarz criterion } & 11.52368 \\
\hline Log likelihood & -1231.120 & \multicolumn{2}{|c|}{ Hannan-Quinn criter. } & 11.47712 \\
\hline F-statistic & 75.04904 & \multicolumn{2}{|c|}{ Durbin-Watson stat } & 1.226886 \\
\hline Prob(F-statistic) & 0.000000 & & & \\
\hline
\end{tabular}


Model without capital employed

\begin{tabular}{|c|c|c|c|c|}
\hline \multicolumn{5}{|c|}{ Dependent Variable: SP } \\
\hline \multicolumn{5}{|c|}{ Method: Panel Least Squares } \\
\hline \multicolumn{5}{|c|}{ Date: 01/12/15. Time: $22: 34$} \\
\hline \multicolumn{5}{|l|}{ Sample: 20062013} \\
\hline \multicolumn{5}{|l|}{ Periods included: 8} \\
\hline \multicolumn{5}{|c|}{ Cross-sections included: 27} \\
\hline \multicolumn{5}{|c|}{ Total panel (balanced) observations: 216} \\
\hline Variable & Coefficient & Std. Error & t-Statistic & Prob. \\
\hline EPS & 3.553438 & 0.346810 & 10.24606 & 0.0000 \\
\hline BVPS & 0.383610 & 0.097154 & 3.948494 & 0.0001 \\
\hline NOCFPS & 0.279667 & 0.133913 & 2.088424 & 0.0380 \\
\hline C & 30.47072 & 7.697387 & 3.958579 & 0.0001 \\
\hline R-squared & 0.586340 & \multicolumn{2}{|c|}{ Mean dependent var } & 115.2794 \\
\hline Adjusted R-squared & 0.580486 & \multicolumn{2}{|c|}{ S.D. dependent var } & 112.7820 \\
\hline S.E. of regression & 73.04883 & \multicolumn{2}{|c|}{ Akaike info criterion } & 11.43848 \\
\hline Sum squared resid & 1131260. & \multicolumn{2}{|c|}{ Schwarz criterion } & 11.50098 \\
\hline Log likelihood & -1231.356 & \multicolumn{2}{|c|}{ Hannan-Quinn criter. } & 11.46373 \\
\hline F-statistic & 100.1659 & \multicolumn{2}{|c|}{ Durbin-Watson stat } & 1.236572 \\
\hline Prob(F-statistic) & 0.000000 & & & \\
\hline
\end{tabular}

\section{Copyright Disclaimer}

Copyright for this article is retained by the author(s), with first publication rights granted to the journal.

This is an open-access article distributed under the terms and conditions of the Creative Commons Attribution license (http://creativecommons.org/licenses/by/3.0/). 